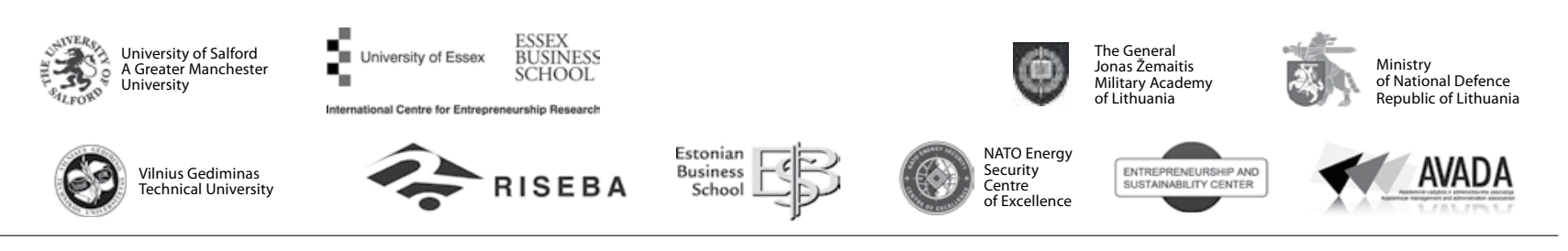

\author{
JOURNAL OF SECURITY AND SUSTAINABILITY ISSUES \\ ISSN 2029-7017 print/ISSN 2029-7025 online \\ 2017 December Volume 7 Number 2 \\ https://doi.org/10.9770/jssi.2017.7.2(8)
}

\title{
THE IMPACT OF VALUE-ADDED TAX ON THE FISCAL SUSTAINABILITY
}

\author{
Egidijus Bikas ${ }^{1}$, Gintautas Bagotyrius ${ }^{2}$, Agnė Jakubauskaitè ${ }^{3}$ \\ ${ }^{1,2}$ Vilnius University, Faculty of Economics, Sauletekio 9 LT-10223, Vilnius, Lithuania \\ ${ }^{3}$ State Tax Inspectorate Under the Ministry of Finance of the Republic of Lithuania, \\ Vasario 16-th str. 14, LT-01514 Vilnius, Lithuania \\ 1'egidijusvln@gmail.com²g.bagotyrius@gmail.com; 3agnes.jakubauskaites@gmail.com
}

Received 17 January 2016; accepted 20 July 2017

\begin{abstract}
The article analyses and summarizes the various author's approach to value-added tax (hereinafter - VAT), its role in the tax system and the impact of VAT revenue on the state budget. The article considers the features of VAT, its positive and negative characteristics, discusses the aspects of implementation of tax function, and identifies the revenue collection determinants examined in literature. The impact of VAT revenues on the European Union (hereinafter - EU) Member States (hereinafter - MS) budgets, and the dynamics of the standard VAT rate and income from VAT collection efficiency is analysed. Having selected four EU Member States (Bulgaria, Italy, Ireland and Lithuania), the method of pair correlation is used to evaluate the economic and VAT describing factors affecting the revenue from VAT collection in these countries. The most correlating factors in each of the selected countries were used to create multiple regression models. After discussing the situation of VAT in the EU, the article analyses the dynamics of the revenue from VAT part in the state budget income. It examines the changes of revenue from VAT, the causes that determined a (non) enforcement of the plan of the revenue from VAT, the efficiency of the collection of revenue from VAT and its reasons analysing the case of Lithuania. In order to identify the factors that determined the revenue from the collection of VAT in Lithuania in the period 2005-2015, three multiple regression models were se up, analysed and summarized.
\end{abstract}

Keywords: VAT, budget revenues, C-effectiveness ratio, multiple regression.

Reference to this paper should be made as follows: Bikas, E.; Bagotyrius, G.; Jakubauskaite, A. 2017. The impact of value-added tax on the fiscal sustainability, Journal of Security and Sustainability Issues 7(2): 267-285. https://doi.org/10.9770/jssi.2017.7.2(8)

JEL Classifications: E20, E21, H20, H21

\section{Introduction}

Indirect taxes attract a lot of attention as the subject of scientific debate. In most of the developed countries, indirect taxes not only remain as the most important component of the tax system and significant revenue source, but also steadily increase their influence on the budget revenue. Having special structure, indirect taxes affect every consumer. The principal indirect tax in the income of the country is VAT.

VAT can be regarded as one of the recently emerged taxes. For the first time, VAT was introduced in 1948 in France. The tax was applied in the production process, but did not include the deduction (for the raw materials purchased and used in the production). In 1954, VAT was introduced as a consumer tax, and at the end of the 6th decade, it has been widely used in many European and Latin American countries. In 1970, VAT was introduced in the EU. It replaced the consumption and production taxes, which were valid in the EU MS, and, in May 1977, the Sixth VAT Directive was adopted for the harmonization of the VAT system within the countries of the 
EU (Sirbulescu et. al., 2004). Bikas et al. (2013) points out that VAT has a significant impact on the common internal market, VAT arrangements in the EU are strictly regulated, and the complex harmonization process that started after establishment of the EU continues until now.

Although the rapid expansion of VAT decreased at the begging of the 8th decade, its rapid increase has begun again after a few years (Bikas, Rashkauskas, 2011). According to Stroe (2011), introduction of VAT had two goals: to replace certain direct taxes and reduce the budget deficit. Legeida and Sologoub (2003) state that VAT is currently applied in more than 120 countries, being the main source of budget revenue in the most countries of the EU. Stačiokas (2003) said that revenue from VAT in all EU MS creates at least 25 per cent of the national budget tax revenues and this share is growing. According to Grinberg (2010), VAT revenue accounts for approximately the fifth of the tax revenues in the world. In summary, it can be stated, that VAT is one of the most important sources of budget income in many countries of the world.

Despite the fact that VAT has relatively a short life history, it ensures a significant share of the budget revenue and strongly dominates in tax revenues in many countries of the world. VAT is applicable to almost all goods and services; therefore, it is acknowledged as universal. Although, due to reduced VAT rates, some goods and services become more accessible to the society, the regress of VAT is regarded as one of the major negative features of the tax. Over the last decade, the average amount of the revenues from VAT in the EU MS reached slightly more than one-fifth of government revenue, and in Lithuania it reached a little more than a quarter.

Revenues from VAT, forming a large part of the state budget revenues, have a strong impact on the implementation of the state functions. With the change of various elements of the tax and economic situation, comprehensive analysis of income from the collection of VAT and its influential factors makes it possible to react quickly to the changing economic situation, accurately plan and to ensure the effectiveness of revenue collection.

The aim of this paper is to analyse the VAT fiscal significance of the state budget revenues and to identify the factors that determine the revenue from the collection of the tax. The chosen research methods are the analysis and summary of Lithuanian and foreign scientific literature, legal documents, grouping of statistical data, the models of correlation and regression.

\section{The essence of value-added tax and its role in formation of the state budget income}

Many authors consider the VAT as the most significant indirect tax in terms of its income contributing to the state budget (Damuliené, Vengrauskas (2001); Bikas, Rashauskas (2011)). This tax has been thoroughly analysed by Metcalf (1995), Liberati (2000), Legeida, Sologoub (2003), Bendikienè, Janišauskienè (2005), Bikas, Rashauskas (2011), Stroe (2011), Ivaškaitė-Tamošiūnè (2014), Simionescu (2015) and other authors. The significance of VAT is indicated by the fact, that the VAT practice is a necessary condition for the countries that want to join the EU (Damuliené, Vengrauskas, 2001). Decoster et al. (2010) consider VAT as a dominant tax in the tax system in the European Union. Bikas and Andruskaite (2013) state that the distribution of VAT in the most of the countries has been influenced by the effectiveness of VAT.

VAT embodies all the chains of economy: from the chain of production and distribution of goods to the actual delivery of goods and services to the consumer (Sirbulescu et. al, 2004). Stroe (2011) similarly describes the scheme of VAT stating that VAT is calculated and applied in each stage of goods and service production, from raw materials to the appearance of the product in the market. I.e. VAT is an added value of taxation, produced during each stage of production process, and for each stage the tax is paid to the state budget (Bendikienè et al., 2006). Nevertheless, considering the fact that VAT is included into the final price of goods and services, all pressure of VAT is eventually put on the final consumer (Štreimikiene et al., 2006). Thus, VAT can be considered as a universal tax. According to Ivaškaitė-Tamošiūnè (2014), VAT is applied to almost all goods and services; therefore, it would be impossible to find a consumer who manages to avoid this tax for a long time. Admittedly, there can be instances of fraud, concealment; however, the ones who benefit in such circumstances are the business subjects rather than the final consumers of goods and services. 
As any other scientific object of analysis, the authors evaluate the VAT from the different perspectives. While the part of the authors highlight its positive features and benefit to the state income and economics; other authors tend to focus on the negative aspects of VAT by revealing the problems that should be resolved in order to improve the tax system (Table 1). It is noticed that literature tends to express the positive evaluation towards VAT emphasising simple administration, however; regress is considered the main drawback of this tax.

Table 1. VAT evaluation

\begin{tabular}{|c|c|}
\hline Positive VAT evaluation & Negative VAT evaluation \\
\hline $\begin{array}{l}\text { Payment mechanism does not allow to avoid the tax; } \\
\text { - Simple collection; } \\
\text { - VAT encourages to work and save up; } \\
\text { - Neutral to business; } \\
\text { - Reflecting in the price is capable to control itself. } \\
\text { Damuliene, Vengrauskas (2001) }\end{array}$ & $\begin{array}{l}\text { - Increases administrational expences; } \\
\text { - Influences the increase of regressive tax. } \\
\text { Damuliené, Vengrauskas (2001) }\end{array}$ \\
\hline $\begin{array}{l}\text { - Helps to keep the activities of legal entities undisturbed; } \\
\text { Provides more opportunities to identify and eliminate the export subsidies } \\
\text { that distort the economic development. } \\
\text { Stačiokas }(2003)\end{array}$ & $\begin{array}{l}\text { - Raising the rate disbalances economy and } \\
\text { negatively influences the level of production. } \\
\text { Dilius, Kareivaite (2010) }\end{array}$ \\
\hline $\begin{array}{l}\text { VAT is one of the steadiest taxes, the income of which is easy to predict. } \\
\text { Legeida, Sologoub (2003) }\end{array}$ & $\begin{array}{l}\text { - VAT is regressive tax. } \\
\text { Stroe (2011) }\end{array}$ \\
\hline $\begin{array}{l}\text { It is easy to administrate, collection of tax requires the minimal funds. } \\
\text { Bendikiené, Janišauskienè (2005) }\end{array}$ & $\begin{array}{l}\text { - Regressive; } \\
\text { - Increases personal income inequality. } \\
\text { Ivaškaitė-Tamošiūnė (2014) }\end{array}$ \\
\hline $\begin{array}{l}\text { - VAT has a less distorting effect on labour market rather than income taxes. } \\
\text { Decoster et al. (2010) }\end{array}$ & \\
\hline $\begin{array}{l}\text { - From the fiscal perspective, VAT is significant in terms of not only indirect } \\
\text { taxes, but also the whole structure of state income. } \\
\text { Bikas, Rashkauskas (2011) }\end{array}$ & \\
\hline $\begin{array}{l}\text { VAT is the main tool to achieve the stability of state income and ensure the } \\
\text { performance of public functions during the times of economic instability. } \\
\text { Bikas, Andruskaite (2013) }\end{array}$ & \\
\hline
\end{tabular}

Source: composed by the authors on the basis of indicated sources

Being one of the major taxes generating income in Lithuania, VAT performs all the functions characteristic for taxation (regulatory, fiscal and allocation). Fiscal function is performed, since the income from VAT constitutes the major part of the budget income (e.g., in 2014, VAT accounted for 50.3\% of the state budget income, excluding the funds of financial support provided by the EU and other foreign countries (LT finance....2005-2017)). Regulatory function, invoking VAT, is performed through the prices. Since this tax is the constituent part of the price for goods and services, increasing the rate of VAT, raises the prices, which leads to the decrease in purchasing power of consumers. Dilius et al. (2010). states that the change of the rate of VAT influences consumption, which affects the level of inflation and level of unemployment. Since VAT is applied to all goods and services, it can be claimed that, due to its distribution, it is a very valuable tool of fiscal politics to change the economic situation of the country. Allocation function in Lithuania has been extensively analysed by Ivaškaitè-Tamošiūnaitė (2014). Although the essence of allocation function is to reduce social exclusion, the research conducted by the author, reveals the opposite tendency. The author claims that VAT is regressive tax that increases the level of population income inequality. VAT regress is highlighted in the conditions of equal consumption level, when low-income consumers spend higher proportion of their income compared to the high-income consumers (Jenkins et al., 2006). Nevertheless, Ivaškaitè-Tamošiūnè (2014) denotes that preferential tariff rates are applied to those groups of goods and services (for instance, for medicine and medical aid, thermal energy), the expenditure on which constitutes a significant part for low-income household budgets, but performs allocation function.

VAT has been established and applied with attempt to comply with principles of taxation; however, it is often that the implementation of all the principles is impossible due to its incompatibility, thus some principles need to be abandoned in order to implement other ones. Ivaškaitė-Tamošiūnè (2014) notices, that in order to guarantee better conditions for social justice, the majority of the EU countries apply more than one VAT rate, thus, 
the principle of administrative simplicity, which could be fully implemented only in case of applying one rate, is offended.

VAT rates (both standard and preferential) are set by each country of the EU individually, however, in order to maintain the structural balance of the EU and avoid distortion of competition, the minimum rates of indirect taxes have been set (Bikas, Andruskaite, 2013). The European Union Council directive 2006/112/EC of 28 November 2006 on the common system of value added tax has agreed on a minimum standard VAT rate of $15 \%$. The directive also denotes that the member countries of the EU will be able to apply one or two preferential rates; while the lowest preferential rate cannot be lower than $5 \%$, (some countries have an exceptional right to set a lower rate).

In Lithuania, apart from standard VAT rate, applied to goods and services, (since the $1^{\text {st }}$ of September, 2009 the rate of $21 \%$ has been set up), the preferential rates are valid as well (Table 2.)

Table 2. Preferential VAT rates in 2017

\begin{tabular}{|c|l|}
\hline Rate & \multicolumn{1}{c|}{ Application object } \\
\hline $5 \%$ & Medicine and medical aid as well as technical aids or equipment for people with disabilities \\
\hline $9 \%$ & $\begin{array}{l}\text { Thermal energy, books, non-periodical informative publications, accommodation establishments, newspapers, magazines and } \\
\text { other periodical publications, passenger transport services }\end{array}$ \\
\hline
\end{tabular}

Source: prepared by the authors in accordance with LR pridètinès..., 2002

Authors have different perspectives on preferential VAT rates. Bikas et al. (2010) consider preferential VAT rates as a tool for income distribution, when particular goods and services are subject to lower rate tax. Legeida at al. (2003), having analysed VAT problems in Ukraine, proposes the idea that preferential rates and other exceptions is one of the major VAT drawbacks. Ivaškaité-Tamošiūne (2014) states that preferential VAT rates have even several positive aspects. Firstly, preferential VAT rates increase the level of effectiveness. Secondly, the application of these rates reduces the financial load for the low-income households, i.e. contributes to ensuring social justice. Thirdly, due to the preferential rates, particular products become more available and attractive to the major part of society. However, having conducted the analysis of percentage part of chargeable VAT and all household expences, Ivaškaitė-Tamošiūnè (2014) notices that slight level of VAT regress remains. This implication reveals that the structure of VAT, established in Lithuania, has a weak impact on achieving a vertical social justice; and tax benefits, possibly do not lead to expected impact, i.e. do not guarantee better conditions for low-income households. Liberati (2000), who analysed the VAT system in Italy, has not identified the impact of preferential VAT rates on social welfare, i.e. during the period of analysis in the years 1988-1997, the preferential VAT rates did not change the consumption structure in Italy. Therefore, it can be assumed that either the VAT system does not have a significant impact on social welfare, or the level or strength of impact depends on the level of development of a particular country. The analysis of VAT in Germany essentially proved Italian analyst's statement about the preferential VAT rates as an ineffective way to distribute income (Boeters et. al, 2006). Therefore, having created different models of scenario, based on which the part or even all preferential rates would be eliminated, the authors conclude that the elimination of preferential VAT rates, applied to their production, would significantly affect the activity and results of particular economic sectors. Bikas et al. (2010) state that preferential VAT rates can serve as subsidies for a particular economic activity, or as a form, that influences the profit and level of employment in this activity.

Decoster et al. (2010), having analysed the differential issue of VAT rates, denoted that different perspectives towards it apply, the effectiveness and justice, in particular. In terms of effectiveness, the higher rates of tax should be applied while charging for inelastic goods and services, and non-necessity goods and services having the purpose of leisure. In terms of justice the lower rates should be applied to those goods that are relatively used by low-income households. To sum up, it can be stated that there is no agreed opinion on preferential VAT rates among the authors. Although the preferential VAT rates has lower or higher impact on income distribution, more effective way to achieve justice among the households with different income could be targeted support, in case of which it should be ensured that it is provided to people who meet a particular set criteria. 
The impact of preferential rates has been analysed from unusual perspective by Dilius et al. (2010). He assessed the impact of benefits on the principle of harmonious development (the essence of principle is that harmonious development requires equal attention to economic, social and environmental progress). Conducted research revealed that applying VAT benefits the economic profit is achieved as well as the social differentiation is reduced; however, the environmental damage is caused. Whereas, while reducing the amount of benefits, only the beneficial impact on ecology is achieved. Thus, achieving harmonious development, VAT benefits are profitable, due to the promotion of production growth, reduction of costs for low-income households, whereas environmental pollution can be resolved by using the income of the high-income rich part of population.

In summary, it is worth to highlight that, despite the considerably short practice of application, VAT has become one of the main taxes in the majority of the countries in the world and this impact has a tendency to grow. Due to this particular reason, it is necessary to research and consider various aspects of VAT, even the smallest changes in VAT taxation can have a considerate impact on both the economy of the whole country and the budget income as well as on the implementation of state functions.

While achieving to collect the desirable income from taxes, it is important not only to know the factors that influence collection, but also evaluate its possible changes and the impact of those changes on the collection of income. The understanding of contextual economical and the whole tax environment is necessary in order to forecast the tax for the nearest periods, which is needed in order to collect desired income and actively react to changing situation.

Scientific literature describes various methods of income from VAT analysis. For instance, Simionescu (2015) uses econometric models (regression model, trends, vector autoregression -VAR model) for the analysis and forecast of quarterly revenue from indirect taxes. Legeida and Sologoub (2003) identifies four main methods of evaluating revenue: 1. Effective rate perspective 2. Elasticity perspective 3. Model (for example, multiplex regression) perspective 4. Autocorrelation perspective. Authors emphasize that all the mentioned methods have their benefits and drawbacks, thus it would be more objective to use as many methods as possible and compare their results.

Analysing scientific literature, various combinations of factors have been detected that influence the income from VAT collection. Legeida and Sologoub (2003) distinguishes two groups of factors that influence the income from VAT collection: 1. Indicators for defining tax (rates, taxation base, the limit that obliges to become a VAT payer etc.) 2. Economic variables. Assuming that the collection of income from VAT is influenced by the similar factors in majority of countries, the influential factors selected by the authors are summarized in table 3.

Table 3. The influential factors for collection of income from VAT

\begin{tabular}{|l|c|l|}
\hline \multicolumn{1}{|c|}{ Author } & \multicolumn{1}{|c|}{ Country and period } & \multicolumn{1}{c|}{ Influential factors } \\
\hline Bikas, Rashkauskas (2011) & Lithuania (1995-2009) & $\begin{array}{l}\text { Standard VAT rate; Difference between standard VAT rate and lowest } \\
\text { preferential VAT rate (not 0\% rate); Level of unemployment; Circulation } \\
\text { limit, that obliges to register as a VAT payer; Number of preferential rate }\end{array}$ \\
\hline $\begin{array}{l}\text { Tamašauskienė, Žadvidaitė } \\
(2011)\end{array}$ & Lithuania (2000-2010 m) & $\begin{array}{l}\text { Standard VAT rate; Average annual inflation; Household consumption ex- } \\
\text { penses; Market volume. }\end{array}$ \\
\hline Bikas, Andruskaite (2013) & EU countries (2004-2011) $)$ & $\begin{array}{l}\text { GDP; Consumption expenses; Household consumption expenses; Export; } \\
\text { Income; GDP per capita }\end{array}$ \\
\hline Kaczynska (2015) & Poland (2000-2013) & GDP; Inflation level; Standard VAT rate. \\
\hline Simionescu (2015) & Romania (2004-2014) & GDP; Part of Social guarantee. \\
\hline
\end{tabular}

Source: compiled by the authors on the basis of indicated sources

To summarize distinguished by the authors influential factors that affect the income from VAT collection, it can be stated that the main factors are considered to be GDP, standard VAT rate, household consumption expenses. Nevertheless, it must be noted that the collection of the income from VAT is influenced by other factors that are difficult to measure: the effectiveness of the tax administration activity, the implementation of new prevention revenue, and, finally, the consciousness of the taxpayers themselves. Therefore, there cannot be one exact 
definite answer what are the influential factors on collecting income from VAT, however, the research and comparison of various combinations allows to clearly determine the main factors, the forecast of which helps to get the more precise income estimates.

\section{Methodology of research on VAT fiscal impact on the state budget income}

The data covering the period from 2005 to 2016 (inclusive) has been analysed, except for the cases when, due to the inaccessibility or expedience of data, the material covering another period was used. Such cases and their reasons described in the analysis of specific data. The analysis of VAT impact on budget revenue in Lithuania starts from examination of the revenue from this tax dynamics, plan execution and the main (non) enforcement reasons. Further, the evaluation of the effectiveness of revenue collection and identification of the key economic factors and their impact on revenues from VAT using the pair correlation and multiple regression techniques is provided.

Revenue from VAT collection efficiency is determined by using $\mathrm{C}$-effectiveness and efficiency indicators:

$$
\begin{aligned}
& \text { Efficiencyratio }=\frac{\frac{\text { VAT revenues }}{\text { StandartVAT rate }}}{\text { Gross domestic product }} \\
& C-\text { efficiency ratio }=\frac{\frac{\text { VAT revenues }}{\text { StandartVAT rate }}}{\text { Final consumption expenditure }}
\end{aligned}
$$

In order to determine the dependence between two quantities, the Pearson's correlation coefficients were the following (Blažytè, Norkuvienè, 2007):

$$
r_{X Y}=\frac{\sum_{i=1}^{n}\left(x_{i}-\underline{x}\right)\left(y_{i}-\underline{y}\right)}{\sqrt{\sum_{i=1}^{n}\left(x_{i}-\underline{x}\right)^{2} \sum_{i=1}^{m}\left(y_{i}-\underline{y}\right)^{2}}}
$$

where: $r$ - correlation coefficient, $y$ - first independent variable ${ }^{l}, \underline{y}$ - average of first independent variable, $x$-second independent variable, $\underline{x}$-average of second independent variable.

In order to identify the main factors, affecting revenues from VAT collection, and the strength of their impact, regression analysis was used. Referring to the knowledge of economic theory, independent variables, potentially affecting VAT revenue collection, were selected for the analysis (Table 4).

1 (in some cases dependent variable - revenues from VAT) 
Table 4. Potential variables of regression to detect VAT revenue collection influencing factors and the size of their impact

\begin{tabular}{|c|c|c|}
\hline Denotation & Title of variable & Units \\
\hline \multicolumn{3}{|c|}{ Dependent variable } \\
\hline $\mathrm{Y}^{\mathrm{VAT}}$ revenue & State budget revenue from VAT & Thousands of Euros \\
\hline \multicolumn{3}{|c|}{ Independent variables } \\
\hline $\mathrm{X}^{\mathrm{FCE}}$ & Final consumption expenditures & Millions of Euros \\
\hline $\mathrm{X}^{\text {rate }}$ & Weighted VAT rate & Percentage \\
\hline $\mathrm{X}^{\mathrm{VAT} \text { payers }}$ & VAT payers number at the end of the period & Unit \\
\hline $\mathrm{X}^{\mathrm{AW}}$ & Average wage & Euros \\
\hline $\mathrm{X}^{\mathrm{ER}}$ & Employment rate & Percentage \\
\hline $\mathrm{X}^{\mathrm{NE}}$ & Net exports & Millions of Euros \\
\hline $\mathrm{X}^{\mathrm{CP}}$ & Changes in consumer prices compared with the same quarter last year & Percentage \\
\hline \multicolumn{3}{|c|}{ Fictitious variable } \\
\hline $\mathrm{D}^{\mathrm{EC}}$ & Economic cycle & - \\
\hline
\end{tabular}

Source: composed by authors

Considering the calculation period of independent variables (Department of Statistics presented a number of indicators for quarterly data) and the specifications of VAT declarations (VAT payers have to submit declaration and pay the calculated VAT for this month activities by the 25th of the next month (LR pridetinès ..., 2002), for example, in February VAT payers submit declaration for January sales, and VAT revenues in February are earned from activities of January), the switch of revenues from VAT within one month has been made. To assess the influence of the VAT rate to VAT revenue, it was chosen to use a weighted VAT rate (data obtained from the Ministry of Finance upon request), which is calculated using reduced VAT rates.

Multiple linear regression is calculated according to Formula 4:

$$
\mathrm{Y}=\beta_{0}+\beta_{1} \mathrm{X}_{1}+\beta_{2} \mathrm{X}_{2}+\ldots+\beta_{\mathrm{n}} \mathrm{X}_{\mathrm{n}}+\varepsilon
$$

where: $Y$-dependent variable (in this case revenues from VAT), $X_{i}$ - independent variables, $\beta_{i}$ - coefficients, $\varepsilon$ - error

In order to perform a regression analysis, it is important to formulate hypotheses that will be later approved or rejected by method of calculation. According to the selected independent variables (Table 4) the hypotheses were formulated (Table 5).

Table 5. Hypothesis of regression to detect VAT revenue collection influencing factors and the size of their impact

\begin{tabular}{|c|l|}
\hline \multicolumn{2}{|c|}{ Hypothesis of regression determination } \\
\hline $\mathrm{H}_{0}$ all $\beta_{\mathrm{j}}=0$ & Regression irrelevant because no variable affects the revenues from VAT \\
\hline $\mathrm{H}_{1}$ at least one $\beta_{\mathrm{j}} \neq 0$ & $\begin{array}{l}\text { Regression statistically significant, because there is at least one variable affecting revenues } \\
\text { from VAT }\end{array}$ \\
\hline $\mathrm{H}_{0}{ }_{0} \beta_{(\mathrm{FCE} / \text { rate/ VAT payers/AW/ER/NE/CP/EC) }}=0$ & $\begin{array}{l}\text { Hypothesis of parameters statistical significance } \\
\text { Final consumption expenditure/ weighted VAT rate/ VAT payers number/ average wage/ } \\
\text { employment/ net exports/ consumer price changes/ economic cycle do not affect the budget } \\
\text { revenues from VAT }\end{array}$ \\
\hline $\mathrm{H}_{1}^{1} \beta_{(\mathrm{FCE} / \mathrm{rat} / \mathrm{VAT} \text { payers/AW/ER/NE/CP/EC) }} \neq 0$ & $\begin{array}{l}\text { Final consumption expenditure/ weighted VAT rate/ number of VAT payers/ average wage/ } \\
\text { employment/ net exports/ consumer price changes/ economic cycle has significant impact on } \\
\text { the budget revenues from VAT }\end{array}$ \\
\hline
\end{tabular}


Before constructing the model of regression, it is necessary to check multicollinearity. For this purpose, the matrix of paired correlation coefficients was created. In order to satisfy the 5th classical regression assumption (i.e. model would lack multicollinearity), the correlation coefficient between independent variables cannot be higher than 0.8. If the model has no characteristics of multicollinearity, the regression equation can be concluded.

After the creation of regression equation, the hypotheses were tested. For this purpose, the statistics of $\mathrm{F}$ and $\mathrm{t}$ were calculated. $\mathrm{F}$ statistics that is used for testing regression statistical significance is calculated using the following formula 5:

$$
F_{k, n-k-1}=\frac{E S S / k}{R S S /(n-k-1)}
$$

For verifying the significance of factors, $t$ statistics, which is calculated according to the formula 6 , is used:

$$
\frac{b_{j}-\beta_{j}}{S E_{b_{j}}}=\frac{b_{j}-0}{S E_{b_{j}}} \sim t_{\frac{\infty}{2}, n-k-k}
$$

As it is important to create multiple regression model, which consists of only the significant independent variables, not necessarily all the variables, listed in Table 4, can have a significant impact on the collection of revenues from VAT. In order to leave only the relevant factors in the final model, Backword procedure was used to remove insignificant factors.

Following backward procedure and leaving only significant independent variables, it was examined, whether formed model has the characteristics of autocorrelation. For this purpose, the Durbin-Watson statistics was used.

Another test that needs to be carried out is the heteroscedasticity verification. In order to determine, if the model does not have the feature of heteroscedasticity, the Goldfield - Quandt test was carried out. After checking the model, hypotheses are adopted or rejected, and the final equation is interpreted.

\section{The research of VAT fiscal impact of budget revenue}

\subsection{VAT fiscal significance of budget revenue in the EU MS}

Revenue from VAT in the EU MS at the analysed period of 2005-2015 amounted to an average of 21.6 percent of total revenue (Table 6). The highest amount of the revenue from VAT is identified among seven EU MS (which in average results in more than 25 percent), which joined the EU in 2004 and later: Croatia, Bulgaria, Romania, Estonia, Lithuania, Cyprus and Latvia. The lowest amount of the revenue from VAT has been identified among seven EU MS (which in average results in less than 18 percent), which can be called as "old-timers" of the Union: Italy, Belgium, France, Spain, Luxembourg, Germany, Austria. Thus, in assessing this data, an initial finding proves that the VAT significance is greater in the new EU MS and less in the older EU MS. 
Table 6. Indicators of VAT in EU MS

\begin{tabular}{|c|c|c|c|c|c|c|c|c|}
\hline \multirow[t]{2}{*}{ EU MS } & \multicolumn{2}{|c|}{$\begin{array}{l}\text { Revenue from VAT part } \\
\text { of the budget revenue }\end{array}$} & \multicolumn{2}{|c|}{$\begin{array}{c}\text { VAT revenue as } \\
\text { percentage of GDP }\end{array}$} & \multicolumn{2}{|c|}{ Standard VAT rate } & \multicolumn{2}{|c|}{$\mathrm{C}$ - efficiency ratio } \\
\hline & Place & Value & Place & Value & Place & Value & Place & Value \\
\hline Croatia & 1 & $32,9 \%$ & 1 & $12,0 \%$ & 4 & $23,3 \%$ & 2 & $66,5 \%$ \\
\hline Bulgaria & 2 & $32,7 \%$ & 3 & $9,3 \%$ & 15 & $20,0 \%$ & 5 & $56,8 \%$ \\
\hline Romania & 3 & $28,1 \%$ & 11 & $7,8 \%$ & 9 & $21,5 \%$ & 18 & $47,2 \%$ \\
\hline Estonia & 4 & $26,5 \%$ & 7 & $8,5 \%$ & 22 & $19,2 \%$ & 4 & $63,0 \%$ \\
\hline Lithuania & 5 & $26,5 \%$ & 12 & $7,6 \%$ & 18 & $19,8 \%$ & 16 & $47,7 \%$ \\
\hline Cyprus & 6 & $26,1 \%$ & 8 & $8,5 \%$ & 27 & $16,2 \%$ & 3 & $65,3 \%$ \\
\hline Latvia & 7 & $25,1 \%$ & 16 & $7,1 \%$ & 14 & $20,0 \%$ & 20 & $45,8 \%$ \\
\hline Portugal & 8 & $22,9 \%$ & 10 & $8,1 \%$ & 8 & $21,6 \%$ & 22 & $44,6 \%$ \\
\hline Slovakia & 9 & $22,6 \%$ & 22 & $6,7 \%$ & 21 & $19,5 \%$ & 19 & $45,9 \%$ \\
\hline Poland & 10 & $22,6 \%$ & 14 & $7,5 \%$ & 6 & $22,5 \%$ & 25 & $42,4 \%$ \\
\hline Malta & 11 & $22,6 \%$ & 15 & $7,5 \%$ & 25 & $18,0 \%$ & 7 & $54,2 \%$ \\
\hline Hungary & 12 & $22,4 \%$ & 6 & $8,5 \%$ & 3 & $24,1 \%$ & 15 & $48,7 \%$ \\
\hline Slovenia & 13 & $22,3 \%$ & 9 & $8,3 \%$ & 13 & $20,5 \%$ & 6 & $56,0 \%$ \\
\hline Ireland & 14 & $21,2 \%$ & 26 & $6,3 \%$ & 7 & $21,8 \%$ & 17 & $47,4 \%$ \\
\hline Finland & 15 & $20,4 \%$ & 5 & $8,6 \%$ & 5 & $22,8 \%$ & 10 & $50,6 \%$ \\
\hline Denmark & 16 & $20,4 \%$ & 2 & $9,6 \%$ & 1 & $25,0 \%$ & 8 & $52,4 \%$ \\
\hline Czech Republic & 17 & $20,2 \%$ & 21 & $6,8 \%$ & 17 & $19,8 \%$ & 12 & $50,4 \%$ \\
\hline Sweden & 18 & $19,9 \%$ & 4 & $8,9 \%$ & 2 & $25,0 \%$ & 13 & $49,9 \%$ \\
\hline Greece & 19 & $19,7 \%$ & 17 & $7,0 \%$ & 10 & $21,0 \%$ & 27 & $38,4 \%$ \\
\hline Netherlands & 20 & $18,2 \%$ & 23 & $6,7 \%$ & 20 & $19,6 \%$ & 14 & $48,8 \%$ \\
\hline United Kingdom & 21 & $18,1 \%$ & 25 & $6,3 \%$ & 24 & $18,4 \%$ & 26 & $40,8 \%$ \\
\hline Austria & 22 & $17,9 \%$ & 13 & $7,6 \%$ & 16 & $20,0 \%$ & 9 & $52,2 \%$ \\
\hline Germany & 23 & $17,5 \%$ & 20 & $6,8 \%$ & 23 & $18,5 \%$ & 11 & $50,5 \%$ \\
\hline Luxembourg & 24 & $17,1 \%$ & 24 & $6,6 \%$ & 28 & $15,2 \%$ & 1 & $89,5 \%$ \\
\hline Spain & 25 & $16,7 \%$ & 28 & $5,7 \%$ & 26 & $17,9 \%$ & 24 & $42,6 \%$ \\
\hline France & 26 & $15,2 \%$ & 18 & $6,9 \%$ & 19 & $19,7 \%$ & 21 & $44,6 \%$ \\
\hline Belgium & 27 & $15,0 \%$ & 19 & $6,9 \%$ & 11 & $21,0 \%$ & 23 & $43,8 \%$ \\
\hline Italy & 28 & $14,1 \%$ & 27 & $5,9 \%$ & 12 & $20,6 \%$ & 28 & $36,2 \%$ \\
\hline EU MS arithmetic average & - & $21,6 \%$ & - & $7,6 \%$ & - & $20,4 \%$ & - & $50,8 \%$ \\
\hline
\end{tabular}

Source: prepared by the authors based on Eurostat data

The average revenue from VAT in the EU Member States in relation to their GDP, during the analysed period, resulted in 7.6 percent (Table 6). Assessing each country indicator, significantly lower variation in amplitude than the average rate of the previous case (respectively from 12.0 percent to 5.7 percent and from 32.9 percent to 14.1 percent) is observed. The highest revenue from VAT on the GDP indicator (which in average results in more than 9 percent) is observed in Croatia, Bulgaria and Denmark, while the lowest (in average reaches less than 6 percent) - Spain and Italy. Lithuania on this indicator takes the 12th position and its value is the same as the average value of the countries of the EU.

EU MS are free to decide on the size of the standard VAT rate, but the fixed standard rate could not be less than 15 percent according to the Directive (European Union Council..., 2006). Over the analysed period, the average standard VAT rate in the EU was equal to 20.4 percent (Table 6). There is a trend of increase of standard VAT rate (the same figure in 2014 was equal to 21.6 percent). Assessing standard VAT rates values of the period of 2005-2015 in each country, 6 countries are regarded as the leaders (the average standard VAT rate greater than 22 percent): Denmark, Sweden, Hungary, Croatia, Finland and Poland. Denmark and Sweden over the analysed 
period maintained a steady 25 percent standard rate of VAT, and Denmark did not apply reduced VAT rates. The lowest standard VAT rates (less than 17 percent) were applied in two countries: Cyprus and Luxembourg. It is noted that Cyprus applied the minimum - 15 percent rate until the 1st of March, 2012, and it has increased to 17 percent since the 1st of March, 2012. In Luxembourg, the standard VAT rate has increased from 15 percent up to 17 percent since the $1^{\text {st }}$ of January, 2015, so currently none of the countries applies the minimum standard VAT rate (the highest rate applied in Hungary - 27 percent). Lithuania, according to the average standard VAT during the analysed period, took the 18 th position.

While evaluating revenues from VAT, it is important to identify revenue collection efficiency as well. For this purpose, VAT collection efficiency ratio is usually calculated. During the period of 2005-2015, the largest average indicator values are observed in Luxembourg, Croatia, Cyprus, Estonia, Bulgaria, and the lowest are seen in Italy, Greece, United Kingdom, Poland and Spain (Table 6). Assessing this indicator, Lithuania took the 16th position among the 28 of the EU MS. It is noted that in 2013-2014 Luxembourg VAT collection efficiency reached and exceeded 100 percent. It can be accurately explained by the impact of reduced VAT rates. Over the analysed period, the country had applied 3 percent and 6 percent reduced VAT rates (for food products, medicine, books and newspapers, cultural events, hotels and restaurants, etc.) (European Commission..., 2015). Therefore, the principal weakness of this indicator could be the fact that the calculation does not consider applied reduced rates, and the limit for the compulsory registration of VAT payers is not assessed. There can be other possible exceptions as well, so the results show only a generalized situation (revenues from VAT collection, if all consumption would be taxed at the standard VAT rate).

For more detailed analysis of the factors that determine the collection of revenue from VAT, 4 countries, where income from VAT value is different, were selected: Bulgaria (the second largest value), Italy (minimum value), Ireland (corresponding to the average value) and Lithuania. Considering the theoretical part of the authors examined studies that used independent variables, 11 economic and VAT-related indicators were chosen, and the influence of seasonality using fictitious variables was evaluated. It is noted that over the period of 2005-2015 the relationship between revenue from VAT and the independent variables was different in different countries. For example, GDP changes were the most significant for revenues from VAT collection in Bulgaria and Lithuania, while there was not such a strong connection in Ireland; the rate of unemployment in Ireland correlated with the average income from VAT, but the connection was inverted; fictitious variables used to define the seasonality were the least important in Lithuania (Table 7).

Table 7. Pair correlation coefficients values between the revenue from VAT and the independent variables in the period of 2005-2015

\begin{tabular}{|c|c|c|c|c|}
\hline Independent variables & Bulgaria & Italy & Ireland & Lithuania \\
\hline GDP, millions of euros & 0,90 & 0,62 & 0,31 & 0,95 \\
\hline Standard VAT rate, percentage & 0,00 & 0,27 & $-0,23$ & 0,49 \\
\hline Final consumption expenditure, millions of euros & 0,84 & 0,61 & 0,10 & 0,95 \\
\hline Household consumption expenditure, millions of euros & 0,83 & 0,46 & 0,10 & 0,95 \\
\hline GDP per capita, euros & 0,90 & 0,54 & 0,45 & 0,94 \\
\hline Export, millions of euros & 0,79 & 0,48 & $-0,37$ & 0,80 \\
\hline Import, millions of euros & 0,88 & 0,68 & $-0,36$ & 0,86 \\
\hline Unemployment rate, percentage & 0,07 & 0,29 & $-0,53$ & 0,09 \\
\hline HICP 12 months moving average, percentage & $-0,22$ & $-0,12$ & 0,39 & 0,00 \\
\hline Minimum reduced rate, percentage & 0,68 & 0,00 & 0,00 & 0,00 \\
\hline Difference between a standard and a reduced minimum rate, percentage points & $-0,68$ & 0,27 & $-0,23$ & 0,49 \\
\hline 2nd quarter of the year & $-0,09$ & $-0,05$ & $-0,58$ & 0,09 \\
\hline 3 rd quarter of the year & 0,29 & $-0,38$ & 0,55 & 0,07 \\
\hline 4 th quarter of the year & 0,31 & 0,39 & $-0,33$ & 0,23 \\
\hline
\end{tabular}

Source: composed by authors based on calculations 
In order to identify factors, which determined revenue from VAT collection in selected countries in 2005-2015, multiple regression models were created (Backward procedure were used for the selection of significant variables, the models were tested for multicollinearity and autocorrelation (Table 8)). Selected independent variables explained largest share of VAT revenues in Ireland, the lowest in Italy, the standard VAT rate was only significant in case of Lithuania.

Table 8. Multiple linear regression, to determine VAT revenues determinants in selected EU Member States in the period of 2005-2015, results

\begin{tabular}{|c|c|c|c|c|}
\hline & Bulgaria & Italy & Ireland & Lithuania \\
\hline $\begin{array}{l}\text { Coefficient of } \\
\text { determination }\left(R^{2}\right)\end{array}$ & 0,904 & 0,65 & 0,97 & 0,92 \\
\hline $\begin{array}{l}\text { Regression significance } \\
\text { (theoretical F statistics) }\end{array}$ & 2,64 & 2,87 & 2,49 & 2,87 \\
\hline Calculated F statistics & $\begin{array}{c}82,5 \text { (model } \\
\text { significant) }\end{array}$ & $\begin{array}{c}22,3 \\
\text { (model significant) }\end{array}$ & $\begin{array}{c}218,2 \text { (model } \\
\text { significant) }\end{array}$ & $\begin{array}{l}\text { 138,9 (model } \\
\text { significant) }\end{array}$ \\
\hline $\begin{array}{l}\text { Multicollinearity } \\
(\text { Pair correlation } \\
\text { coefficients }<0,8 ; \\
\text { VIF }<5 \text { ) }\end{array}$ & $\begin{array}{c}\text { There is no } \\
\text { Multicollinearity } \\
\text { VIF (FCE) }=4,9 \\
\text { VIF (Import) }=4,7 \\
\text { VIF(Difference) }=3,6 \\
\text { VIF(3rd quarter) }=1,1\end{array}$ & $\begin{array}{l}\text { There is no } \\
\text { Multicollinearity Pair } \\
\text { correlation coefficients } \\
\text { were less than } 0,8\end{array}$ & $\begin{array}{l}\text { There is no } \\
\text { Multicollinearity Pair } \\
\text { correlation coefficients } \\
\text { were less than } 0,8\end{array}$ & $\begin{array}{l}\text { There is no } \\
\text { Multicollinearity } \\
\text { Pair correlation } \\
\text { coefficients were } \\
\text { less than } 0,8\end{array}$ \\
\hline $\begin{array}{l}\text { Autocorrelation } \\
\text { (Theoretical Durbin- } \\
\text { Watson test values) }\end{array}$ & $\begin{array}{c}\mathrm{DL}=1,098 \\
\mathrm{DU}=1,518 \\
4-\mathrm{DU}=2,482 \\
4-\mathrm{DL}=2,902\end{array}$ & $\begin{array}{c}\mathrm{DL}=1,149 \\
\mathrm{DU}=1,546 \\
4-\mathrm{DU}=2,544 \\
4-\mathrm{DL}=2,851\end{array}$ & $\begin{array}{c}\mathrm{DL}=1,098 \\
\mathrm{DU}=1,518 \\
4-\mathrm{DU}=2,482 \\
4-\mathrm{DL}=2,902\end{array}$ & $\begin{array}{c}\mathrm{DL}=1,149 \\
\mathrm{DU}=1,456 \\
4-\mathrm{DU}=2,544 \\
4-\mathrm{DL}=2,851\end{array}$ \\
\hline $\begin{array}{l}\text { Estimated Durbin- } \\
\text { Watson test value }\end{array}$ & $\begin{array}{c}2,541 \\
\text { (Uncertainty area) }\end{array}$ & $\begin{array}{c}2,47 \text { (There is no } \\
\text { autocorrelation) }\end{array}$ & $\begin{array}{l}1,9 \text { (There is no } \\
\text { autocorrelation) }\end{array}$ & $\begin{array}{c}1,41 \\
\text { (Uncertainty area) }\end{array}$ \\
\hline $\begin{array}{l}\text { Final multiple } \\
\text { regression equation }\end{array}$ & $\begin{array}{c}\text { VAT revenue }= \\
-337,8+0,08 * \mathrm{FCE}+ \\
0,07 * \text { Import }+1392,8 * \\
\text { Difference }+ \\
102,7 * 3 \text { rd quarter }\end{array}$ & $\begin{array}{c}\text { VAT revenue }=4500,2+ \\
0,03 * \mathrm{FCE}+0,08^{*} \\
\text { Import- } 1079,4 * 3 \mathrm{rd} \\
\text { quarter }\end{array}$ & $\begin{array}{c}\text { VAT revenue }= \\
1802,4+0,05 * \text { GDP-7386,7* } \\
\text { Unemployment }-1212,0 * 2 \text { nd } \\
\text { quarter }+210,6 * 3 \text { rd } \\
\text { quarter- } 937,5 * 4 \text { th quarter }\end{array}$ & $\begin{array}{c}\text { VAT revenue }= \\
107,9-1234,4 * \\
\text { Standard VAT } \\
\text { rate }+0,12 * \\
\text { FCE- } 6,45^{*} \text { HICP }\end{array}$ \\
\hline
\end{tabular}

Source: composed by authors based on calculations

Therefore, different factors and their combinations influence the collection of revenues from VAT among different EU Member States. In order to better identify the variables that affect the dependent variable, a detailed examination of each country's peculiarities of application of VAT and other specific factors should be done. It has been conducted for the case of Lithuania.

\subsection{Analysis of the structure and dynamics of revenue from VAT, plan execution and collection efficiency evaluation in Lithuania}

The largest VAT value in the state budget, expressed by the income from the part of this tax that contributes to the total revenue (excluding the EU and other international assistance funds), reached 51.6 percent in 2011. In that year, compared with 2010, revenues from VAT increased by 3.2 percent more than the total state budget revenues. Lowest revenue from VAT value, observed at the beginning of the analysed period, corresponds to 39.8 percent (Figure 1). 


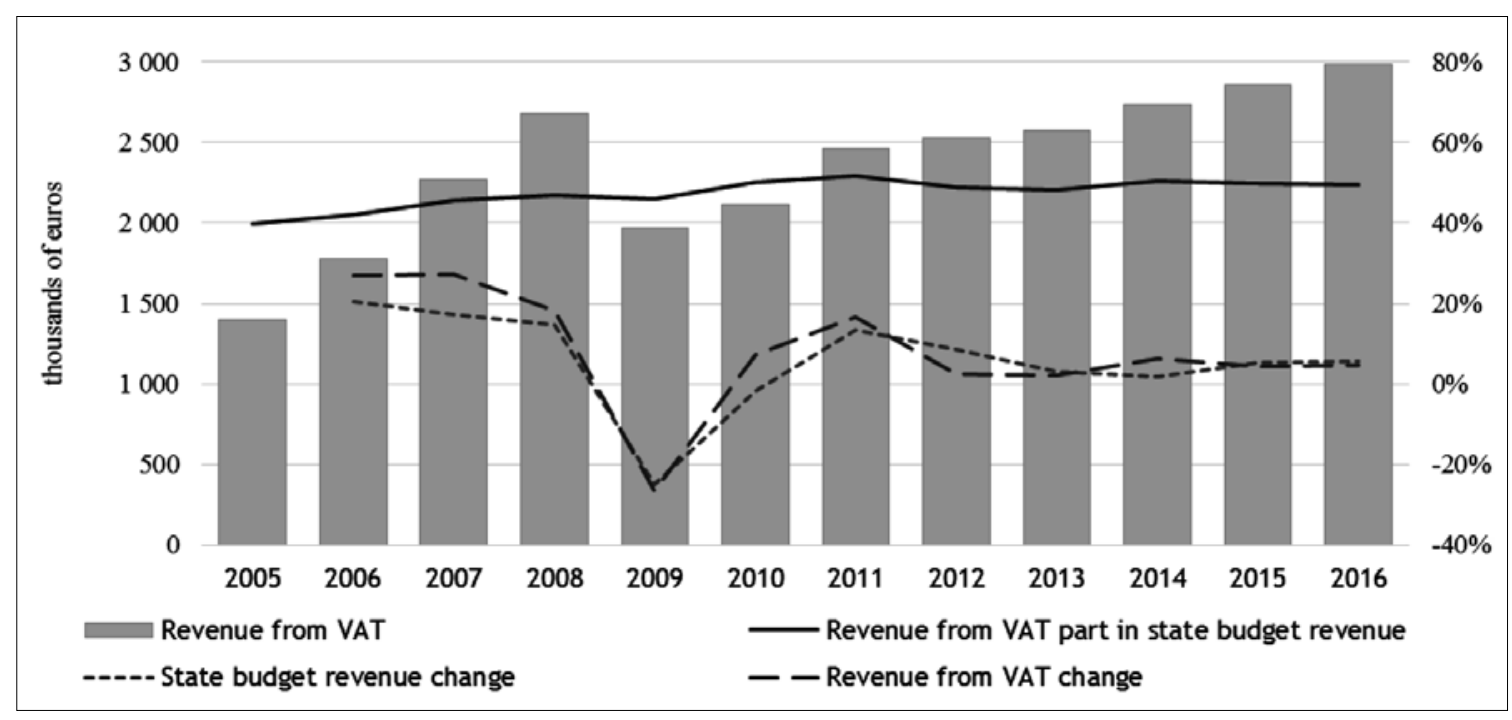

Fig. 1. VAT revenue part of the state budget revenues and revenues form VAT developments in period of 2005-2016.

Source: composed by authors

In summary, it can be said that the revenue from VAT in the state budget revenues during the analysed period has grown, so in Lithuania it is confirmed by growing trend of VAT importance in state budget, which is noticed and analysed by many authors around the world.

In analysed period of 2005-2016 in Lithuania, the increase of the annual state budget revenues from VAT is noticed, with the exception in 2009, when the VAT revenue decreased to 26.4 percent, compared with 2008. Since VAT is a consumption tax, therefore, consumption changes had a substantial impact on the reduction of revenues from the VAT. According to the Department of Statistics, in 2009 final consumption expenditure decreased to 12.1 percent, compared to 2008. Revenue from the VAT reduction was influenced by changing the standard rate of VAT twice in 2009. Since the 1st of January, 2009, the VAT rate of 19 percent has been established (until the entire analysed period the VAT rate has not been changed and it corresponded to 18 percent). Moreover, since the 1st of September, 2009, VAT rate has been enlarged by two percentage points with total of 21 percent size and remained so until now. Another indicator, which is related to the income from VAT notable decrease, price changes in particular, also affected by the VAT rate increase, because it is a component of the price of goods and services. According to the Department of Statistics in December, 2009, consumer prices change, calculated according to the harmonized consumer price index, was equal to 4.2 percent (for the last 12 months, compared with the corresponding previous 12 months). This price rise could have been one of the major causes of decrease in consumption and of the revenue from the VAT reduction at the same time. In this case, the shadow, illegal activities that particularly activates during an economic recession should be taken into consideration. Consequently, revenues from VAT in 2009 significantly decreased due to the economic downturn and the increased VAT rate did not bring the desired effect of increased revenue collection. In assessing the revenue from the basic VAT rates of change, it is noted that throughout the period the revenue from VAT increased by 2.1 times.

Based on planned and actual indicators of revenues from VAT, it is noted that the plan was carried out in 2005-2007 and in 2009-2011 (Table 8). In 2008, when the planned revenue from VAT was the highest throughout the period, while the actual revenue was only higher just in 2014-2015, the plan execution amounted to only 90.9 percent and 266.9 million euros, and had not been collected compared to planned revenues. 
Table 9. State Budget planned and actual revenues from VAT in 2005-2017 in thousands euros and the rate of change in percent

\begin{tabular}{|c|c|c|c|c|c|c|c|c|}
\hline & \multirow{2}{*}{$\begin{array}{l}\text { Planned } \\
\text { revenues }\end{array}$} & \multirow{2}{*}{$\begin{array}{l}\text { Actual } \\
\text { revenue }\end{array}$} & \multicolumn{2}{|c|}{ Plan execution } & \multicolumn{2}{|c|}{$\begin{array}{l}\text { Planned revenues change } \\
\text { rate, percentage }\end{array}$} & \multicolumn{2}{|c|}{$\begin{array}{l}\text { Actual revenues change } \\
\text { rate, percentage }\end{array}$} \\
\hline & & & $+/-$ & Percentage & Basic & Chain & Basic & Chain \\
\hline 2005 & 1298925 & 1402261 & 103336 & $108,0 \%$ & $100,0 \%$ & $\mathrm{x}$ & $100,0 \%$ & $\mathrm{x}$ \\
\hline 2006 & 1720663 & 1781805 & 61142 & $103,6 \%$ & $132,5 \%$ & $132,5 \%$ & $127,1 \%$ & $127,1 \%$ \\
\hline 2007 & 2062209 & 2266038 & 203829 & $109,9 \%$ & $158,8 \%$ & $119,8 \%$ & $161,6 \%$ & $127,2 \%$ \\
\hline 2008 & 2943730 & 2676801 & -266929 & $90,9 \%$ & $226,6 \%$ & $142,7 \%$ & $190,9 \%$ & $118,1 \%$ \\
\hline 2009 & 1810614 & 1969075 & 158461 & $108,8 \%$ & $139,4 \%$ & $61,5 \%$ & $140,4 \%$ & $73,6 \%$ \\
\hline 2010 & 1760271 & 2112496 & 352225 & $120,0 \%$ & $135,5 \%$ & $97,2 \%$ & $150,6 \%$ & $107,3 \%$ \\
\hline 2011 & 2392030 & 2462504 & 70474 & $102,9 \%$ & $184,2 \%$ & $135,9 \%$ & $175,6 \%$ & $116,6 \%$ \\
\hline 2012 & 2586077 & 2524875 & -61202 & $97,6 \%$ & $199,1 \%$ & $108,1 \%$ & $180,1 \%$ & $102,5 \%$ \\
\hline 2013 & 2690971 & 2574385 & -116586 & $95,7 \%$ & $207,2 \%$ & $104,1 \%$ & $183,6 \%$ & $102,0 \%$ \\
\hline 2014 & 2826542 & 2733495 & -93047 & $96,7 \%$ & $217,6 \%$ & $105,0 \%$ & $194,9 \%$ & $106,2 \%$ \\
\hline 2015 & 2943465 & 2895223 & -48242 & $98,4 \%$ & $226,6 \%$ & $104,1 \%$ & $206,5 \%$ & $105,9 \%$ \\
\hline 2016 & 3049577 & 2989582 & -59995 & $98,0 \%$ & $234,8 \%$ & $103,6 \%$ & $213,2 \%$ & $103,3 \%$ \\
\hline 2017 1st quarter & 839794 & 857577 & 17783 & $102,1 \%$ & $\mathrm{x}$ & $\mathrm{x}$ & $\mathrm{x}$ & $\mathrm{x}$ \\
\hline
\end{tabular}

Source: composed by authors based on data from the Ministry of Finance

One of the main reasons for failure to execute the plan is defined by State Tax Inspectorate as a dropping level of consumption growth as well as the dropping growth of revenue from market sales in the main economic sectors (VMI administruojamų..., 2009). Assessing the monthly data, it is noticed that, despite the fact that the plan was not executed in none of the months in the first half of the year, the level of execution reached 90 percent with the average rate of 98.5 percent in the second half of 2008. The execution of the plan of VAT revenue has averagely reached 84 percent, and the biggest gap between the actual and planned revenue from VAT has been recorded in October, when actual revenue was 34.9 percent lower than it was planned. The period of 2012-2015, when the plan execution reached 95,7-98,4 percent, is considered to be the second period when the plan for revenue from VAT has not been implemented. In 2014, the Ministry of Finance gives the main following reasons for failure accomplish the plan (the level of accomplishment reached 96,7 percent): in 2014 the growth of FCE reached 5,6 percent, when the planned revenue was higher with 0,3 percent estimates; on $31^{\text {st }}$ December 2014, arrear of VAT was 32,7 million euros smaller compared to the $31^{\text {st }}$ December, 2013. However, while creating the plan in 2014 and aiming to pay more attention to timely and accurate execution of obligations, it was forecasted that the arrear of VAT should decrease to 58 million euros.

The discussed above, the plan for the revenue from VAT in 2009, has been executed with the rate of even 108,8 percent. The planned revenue was 38,5 percent lower than in 2008 ; while the factual income collected decreased to 26,4 percent compared to 2008. Nevertheless, it is worth noting, that in 2009 the plan for revenue from VAT has been changed a couple of times, an the final plan for revenue from VAT was 33 percent lower than in the initial "Act on confirming the financial rates in State budget and Municipality budget in 2009". Therefore, it can be stated that the execution of the plan in 2009 was artificial.

The most recent data of the first quarter of 2017 shows the improving trends: during the $1^{\text {st }}$ quarter the plan has been executed with 102,1 percent, while the same indicator reached 100,4 percent in 2016, and only 95,6 percent in 2015.

While analysing the collection of revenue from VAT, it is important to not only evaluate the changes, but also the effectiveness of collection. For this purpose, the efficiency and c-efficiency ratio has been calculated (Figure 2) 


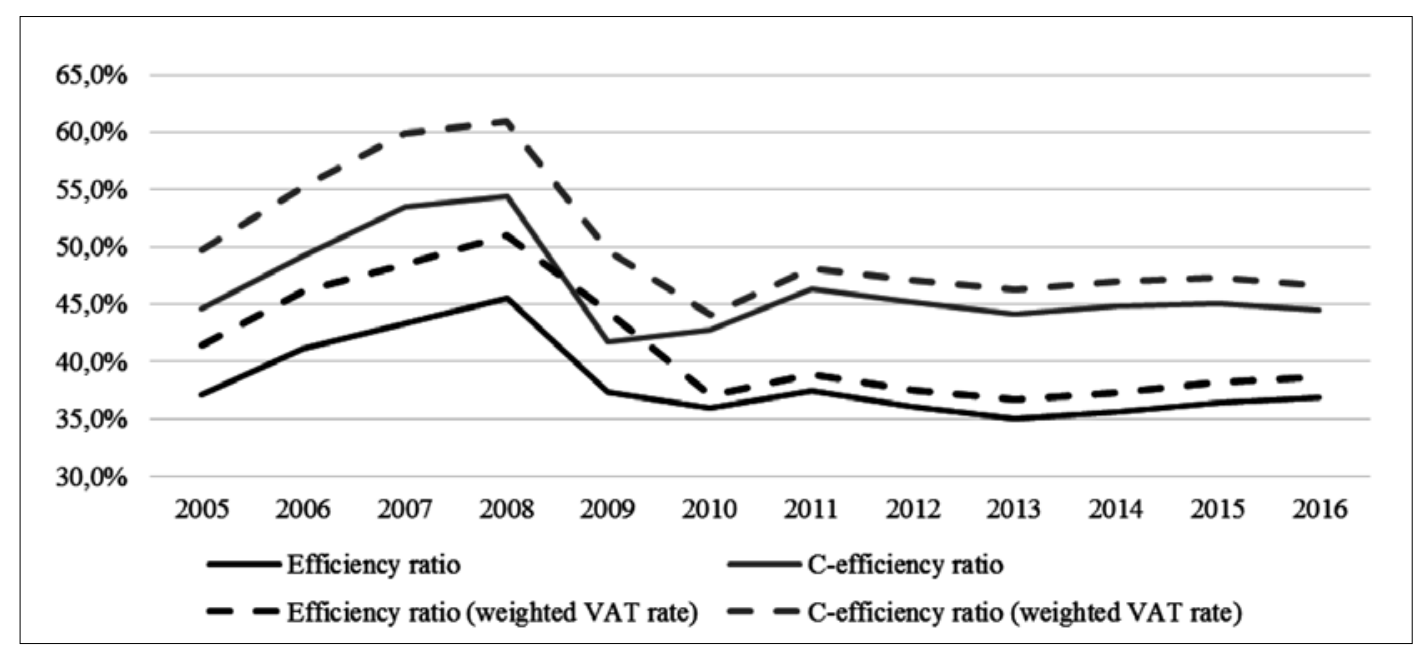

Fig. 2. Revenue from VAT collection efficiency indicators dynamics in 2005-2016, in percentage.

Source: composed by authors based on calculations

Traditionally, in order to evaluate the efficiency, the standard VAT rate is used. Three periods are noticed: the increase of efficiency in 2005-2008, the decrease of efficiency in 2009-2010 and slightly growing efficiency in 2011-2016, but still equal or slightly smaller ratio than in 2005. Due to this, using the data of weighted VAT rate, the rate of efficiency has been calculated by evaluating the influence of reduced rates applied that year. It is noted that the values of these indicators are higher than the value of the rates, which are calculated using the standard VAT rate; however, since 2010 the significant convergence of values is noticed due to the shortening of the list of the goods and services, to which the reduced VAT rate is applied. Although the major changes, related to reduced rate application, has been implemented in 2009, the values of the analysed rates do not reflect it, since the revenue from VAT decreased more than FCE and GDP (accordingly, -21,2 percent, -12,1 percent and $-17,6$ percent). Also the change of rate of standard VAT had influence.

Apart from reduced VAT rates, the collection efficiency ratio is influenced by not only the deliberate undeclared or unpaid VAT by the taxpayer, but also the law statement on VAT, e.g. the taxpayers, who's profit level is smaller than constituted by the law, are not obliged to register as a VAT payers and pay VAT to the budget. In addition, the rate of efficiency level of collecting revenue from VAT in time line is influenced by constructing the budget on the taxing principle. According to the legal act on constructing the budgets, all the contributions paid to the collective accounts of the tax administrating institutions that year, are considered to be the revenue for the particular year, i.e. the revenue of that year is considered to be those contributions, which were paid revising the declarations of VAT (according to LT VAT legal act, the declarations can be revised by the taxpayers for the current and 5 previous years) or in case of ingathering until the termination date, as well as payments for the previous years' activities or penalties. Thus, while evaluating the collection of revenue from VAT effectiveness dynamics, it is important to take into consideration both taxing and other more complex calculable factors.

\subsection{Influential factors for Budget Revenue from VAT}

The size of state budget revenue from VAT is influenced by various factors (economic, political-legal, administrational etc.). In order to determine the major influential factors for collecting budget revenue from VAT in 2005-2015, the linear multiple regression method has been selected. The adjusted dependent variable, budget income from VAT and independent variables are described in the methodology section (Table 3)

Before deriving regressive equation, multicollinearity verification has been conducted (Table 10). 
Table 10. Paired correlation coefficients among multiple regression variables

\begin{tabular}{|c|c|c|c|c|c|c|c|c|c|}
\hline & A & B & $\mathrm{C}$ & $\mathrm{D}$ & $\mathrm{E}$ & $\mathrm{F}$ & $\mathrm{G}$ & $\mathrm{H}$ & I \\
\hline A & 1 & & & & & & & & \\
\hline B & 0,520 & 1 & & & & & & & \\
\hline $\mathrm{C}$ & 0,831 & 0,805 & 1 & & & & & & \\
\hline D & 0,882 & 0,516 & 0,869 & 1 & & & & & \\
\hline $\mathrm{E}$ & 0,896 & 0,570 & 0,925 & 0,936 & 1 & & & & \\
\hline $\mathrm{F}$ & 0,113 & $-0,483$ & $-0,219$ & 0,104 & $-0,120$ & 1 & & & \\
\hline $\mathrm{G}$ & 0,230 & 0,733 & 0,638 & 0,317 & 0,375 & $-0,398$ & 1 & & \\
\hline $\mathrm{H}$ & 0,101 & $-0,574$ & $-0,296$ & 0,039 & 0,030 & 0,286 & $-0,715$ & 1 & \\
\hline I & $-0,110$ & 0,003 & 0,075 & $-0,019$ & 0,186 & $-0,633$ & 0,164 & $-0,017$ & 1 \\
\hline A & \multicolumn{9}{|c|}{ State budget revenue from VAT, thousands of euros } \\
\hline $\mathrm{B}$ & \multicolumn{9}{|c|}{ Weighted VAT rate, percentage } \\
\hline $\mathrm{C}$ & \multicolumn{9}{|c|}{ VAT payers number at the end of the period, unit } \\
\hline $\mathrm{D}$ & \multicolumn{9}{|c|}{ Final consumption expenditures, millions of euros } \\
\hline $\mathrm{E}$ & \multicolumn{9}{|c|}{ Average wage, euros } \\
\hline $\mathrm{F}$ & \multicolumn{9}{|c|}{ Employment rate, percentage } \\
\hline G & \multicolumn{9}{|c|}{ Net exports, millions of euros } \\
\hline $\mathrm{H}$ & \multicolumn{9}{|c|}{ Changes in consumer prices compared with the same quarter last year, percentage } \\
\hline I & \multicolumn{9}{|c|}{ Economic downturn } \\
\hline
\end{tabular}

Source: composed by the authors based on calculations

It has been identified that paired correlation coefficients between final consumption expenditures and average wage, between VAT payers number and final consumption expenditures as well as VAT payers number and Average wage are higher than the allowed limit of 0,8 . One of the most precise solutions of this problem is the elimination of one of strongly correlated factors. Eliminated is the factor, whose correlation with variable is smaller. In this case, the indicators of paired correlation coefficient as well as the rates of all three strongly correlating factors are higher than 0,8 . Since all the independent variables correlate with dependent variable, it was decided to derive three regressive equations, the difference between which would be the indicated independent variables. In the first equation the VAT payers' number and average wage is eliminated, in the second - VAT payers' number and final consumption expenditures, in the third - final consumption expenditures and average wage.

All three derived multiple determination coefficients are bigger than 0,8 , so in all cases the amount of more than 80 percent of revenue from VAT determined the choice of independent variables (Table 11).

Having compared theoretical $\mathrm{F}$ value and having calculated $\mathrm{F}$ value according to 3 models with 95 percent level of dependence the $\mathrm{H}_{0}$ hypothesis is rejected, i.e. constructed regressive models are statistically significant.

Table 11. Multiple determination coefficients and statistical significance indicators for all models

\begin{tabular}{|c|c|c|c|c|c|}
\hline \multirow{2}{*}{ Model } & \begin{tabular}{c} 
Initial model \\
\cline { 2 - 5 } \\
of determination \\
$\left(\mathrm{R}^{2}\right)$
\end{tabular} & $\begin{array}{c}\text { Regression significance } \\
(\mathrm{F} \text { theoretical }-2,389 ; \text { when } \\
\alpha=0,05 ; \mathrm{k}=6 ; \mathrm{n}-\mathrm{k}-1=33)\end{array}$ & $\begin{array}{c}\text { Foefficient of } \\
\text { determination }\left(\mathrm{R}^{2}\right)\end{array}$ & $\begin{array}{c}\text { Regression significance } \\
(\mathrm{F} \text { theoretical }-2,866 \\
(\mathrm{I}) ; 2,641(\mathrm{II} \text { ir III) })\end{array}$ & $\begin{array}{c}\text { Durbin }- \text { Watson test } \\
\text { values }\left(\mathrm{D}_{\mathrm{L}}=1,149 ;\right. \\
\mathrm{D}_{\mathrm{U}}=1,456(\mathrm{I}) ; \mathrm{D}_{\mathrm{L}}=1,098 ; \\
\mathrm{D}_{\mathrm{U}}=1,518(\mathrm{II} \text { ir III)) }\end{array}$ \\
\hline I & 0,835 & 27,881 & 0,811 & 51,575 & 2,769 \\
\hline II & 0,904 & 51,648 & 0,896 & 75,777 & 2,405 \\
\hline III & 0,897 & 47,816 & 0,891 & 71,230 & 2,343 \\
\hline
\end{tabular}

Source: composed by the authors based on calculations 
Since not all the values of the factors, calculated using $t$ statistical model, are bigger thank theoretical $t$ value (Table 12), it means the models has insignificant independent variables. In order to reject statistically insignificant factors backward procedure has been conducted.

Table 12. The significance of the independent variables and coefficients Goldfield-Quandt test values

\begin{tabular}{|c|c|c|c|}
\hline Independent variable & $\begin{array}{l}\text { t values before Backward } \\
\text { procedure } \\
\text { (t theoretical }-2,035 \text {; } \\
\text { when } \alpha=0,05 ; \mathrm{n}-\mathrm{k}-1=33 \text { ) }\end{array}$ & $\begin{array}{l}\mathrm{t} \text { values after Backward procedure } \\
\mathrm{t} \text { theoretical }-2,028 \text {, when } \alpha=0,05 \text {; } \\
\mathrm{n}-\mathrm{k}-1=36 \text { or } 2,03 \text {, when } \mathrm{n}-\mathrm{k}-1=35 \text { ) } \\
\text { or step number of the rejection. }\end{array}$ & $\begin{array}{c}\text { Goldfield-Quandt test value } \\
\text { (theoretical value }-3,287 ; \text { when } \\
\alpha=0,05 ; \mathrm{k}=3 ; \mathrm{n}-\mathrm{k}-1=15 \text { (I) ir } 3,112 ; \\
\text { kai } \alpha=0,05 ; \mathrm{k}=4 ; \mathrm{n}-\mathrm{k}-1=14 \text { (II; III)) }\end{array}$ \\
\hline \multicolumn{4}{|c|}{ I model: } \\
\hline Weighted VAT rate & 2,777 & 2,350 & 0,573 \\
\hline FCE & 3,968 & 7,583 & 0,963 \\
\hline Employment rate & 1,647 & No. 3 & - \\
\hline Net exports & $-0,644$ & No. 1 & - \\
\hline Changes in consumer prices & 2,130 & 2,299 & 1,350 \\
\hline Economic cycle & 0,761 & No. 2 & - \\
\hline \multicolumn{4}{|c|}{ II model: } \\
\hline Weighted VAT rate & 2,198 & 3,886 & 0,799 \\
\hline Average wage & 7,103 & 8,592 & 2,180 \\
\hline Employment rate & 1,994 & 5,178 & 1,038 \\
\hline Net exports & $-1,267$ & No. 2 & - \\
\hline Changes in consumer prices & 1,168 & 2,835 & 1,231 \\
\hline Economic cycle & $-0,760$ & No. 1 & - \\
\hline \multicolumn{4}{|c|}{ III model: } \\
\hline Weighted VAT rate & 1,312 & No. 2 & - \\
\hline VAT payers number & 6,698 & 14,345 & 0,657 \\
\hline Employment rate & 2,410 & 3,238 & 0,988 \\
\hline Net exports & $-2,356$ & $-2,367$ & 0,790 \\
\hline Changes in consumer prices & 2,633 & 2,228 & 1,251 \\
\hline Economic cycle & 0,494 & No. 1 & - \\
\hline
\end{tabular}

Source: composed by authors based on calculations

Having rejected the insignificant factors by remaining independent variables statistical module bigger than theoretical $\mathrm{t}$ statistics, thus backward procedure is completed and the final equations are derived:

I model: $\mathrm{Y}^{\mathrm{VAT} \text { revenue }}=-249.293,3+1.488 .811,9 * \mathrm{X}^{\mathrm{rate}}+83,5^{*} \mathrm{X}^{\mathrm{FCE}}+8.023,1 * \mathrm{X}^{\mathrm{CP}}+\mathrm{e}$;

II model: $\mathrm{Y}^{\mathrm{VAT} \text { revenue }}=-1.207 .867,8+2.235 .912,4^{*} \mathrm{X}^{\text {rate }}+817,4^{*} \mathrm{X}^{\mathrm{AW}}+16.837,4^{*} \mathrm{X}^{\mathrm{ER}}+7.761,0^{*} \mathrm{X}^{\mathrm{CP}}+\mathrm{e}$;

III model: $\mathrm{Y}^{\mathrm{VAT} \text { revenue }}=-897.392,8+13,7^{*} \mathrm{X}^{\mathrm{VAT} \text { payers }}+10.018,1^{*} \mathrm{X}^{\mathrm{ER}}-65,3^{*} \mathrm{X}^{\mathrm{NE}}-6.463,9^{*} \mathrm{X}^{\mathrm{CP}}+\mathrm{e}$.

The final coefficients of multidimensional determination as well as the statistical values of statistical significance $\mathrm{F}$ are depicted in table 11.

In order to determine, whether the created models do not have features of autocorrelations, Durbin - Watson test (for coefficient values see table 11) has been done. I model fall into the area of indetermination/uncertainty, thus it is impossible to state whether the model has the features of autocorrelation. The models II and III are not marked by the correlation.

In order to determine whether the created models have the features of heteroscedasticity, Goldfield- Quandt test has been done (for the coefficient values see table 12). Since the values of all the independent variables calculated in the test are smaller than the theoretical one, thus, created models does not have the features of heteroscedasticity, i.e. are homoscedastic. 
Thus, the final linear equations are suitable, reliable and on relatively high level revealing the changes of revenue from VAT in 2005-2015. Thus, the zero hypothesis are rejected (hypotheses analysis in section 2, table 5):

I model: $\mathrm{H}^{2}{ }_{0} \beta^{\text {rate }}=0 ; \mathrm{H}_{0}{ }_{0} \beta^{\mathrm{FCE}}=0$ ir $\mathrm{H}_{0}^{7} \beta^{\mathrm{CP}}=0$;

II model: $\mathrm{H}_{0}^{2} \beta^{\text {rate }}=0 ; \mathrm{H}_{0}^{4} \beta^{\mathrm{AW}}=0 ; \mathrm{H}^{5}{ }_{0} \beta^{\mathrm{ER}}=0$ ir $\mathrm{H}^{8}{ }_{0} \beta^{\mathrm{EC}}=0$;

III model: $\mathrm{H}_{0}^{3} \beta^{\text {VAT payers }}=0 ; \mathrm{H}^{5}{ }_{0} \beta^{\mathrm{ER}}=0 ; \mathrm{H}^{6}{ }_{0} \beta^{\mathrm{NE}}=0$ ir $\mathrm{H}^{7}{ }_{0} \beta^{\mathrm{CP}}=0$.

I.e. the influence of these combinations of independent variables is significant for collection of revenue from VAT.

Evaluating on the basis of multiple determination coefficient, it would be more precise to use the model II, in which determined independent variables determined 89.6 percent of budget revenue from VAT during the period of 2005-2015 or 89.6 percent of the general average variation of budget revenue from VAT is determined by the changes of selected independent variables.

Summarizing, it can be stated that during the period of 2005-2015 the collection of revenue from VAT has been affected by all the selected independent variables (only the economic cycle was not an influential factor in none of the models, since its influence was indirect and was reflected only through different factors, such as final consumption expenditures, average wage). The change of consumer prices has been an influential factor in all the constructed models. Thus, the revenue from VAT depends on both economic indicators and indicators related to VAT regulation.

\section{Conclusions}

1. Indirect taxes is the most important type of budget tax incomes in most of the counties. A significant role is played by VAT, from which an important part of collected revenue contributes to state budget income. VAT is evaluated as a neutral to business subject activities, easily administrated, except for applied reductions. VAT reduced rates are significant in achieving the legitimate taxation as well as useful for harmonious economy, the development of social and ecological sphere. VAT as a percentage part of the price can affect the increase of the prices, since the salespeople and the service providers tend to move the pressure of taxation on the consumer. The rising prices reduce consumption, thus, the increase in VAT rate does not necessarily will affect the increase of budget income.

2. The revenue from VAT in the analysed period of 2005-2016 in Lithuania, in average corresponded to 47,4 percent of the whole state budget income (excluding the EU and other foreign support funds) VAT fiscal value for state budget income, expressed by structural part, has been growing throughout the period of analysis.

3. While analysing the VAT fiscal influence for budget income among the members of the EU, it has been noticed that highest level of contributions of the revenue from VAT to the budget income is dominating among the recent members of the EU, i.e. those who joined EU from 2004 and onwards, and the lowest level prevails among the "old-timers". Evaluating the efficiency of the collection of revenue from VAT, it has been noticed that at the end of the period, in Luxembourg the rate exceeded 100 percent, however this result and the uniqueness among EU countries was relatively influenced not by more efficient administration of taxation, but widely applied significantly low reduced rates. According to this rate, Lithuania took the $16^{\text {th }}$ position. Since the beginning of analysed period, the collection of revenue from VAT efficiency coefficient reached its peak in 2008. Due to the revelation of "overnight reforms" the level significantly decreased and only for the last years has been recovering. In order to get rid of the reduced VAT rates influence in the process of calculation of this rate, the same rate has been calculated applying weighted VAT rate data, which resulted in higher rates. Notably, apart from the revenue from reduced VAT rates, the efficiency of collection is affected by legal regulations on VAT taxation and considering income as revenue.

4. The revenue from VAT plan has not been executed for 4 years in a row $n$ Lithuania. In 2016, the revenue from VAT plan was not completed, since the growth of GDP did not coincide with forecast, on the basis of which the 
state budget for 2016 was prepared. In order to change this tendency, the methodology on planning the revenue from VAT is revised, the activity of taxation administration institutions are changed. Moreover, it is necessary to continue raising taxpayers' consciousness and public intolerance towards avoiding taxation. It could be said, these measures are already produces a result - the most recent data of the first quarter of 2017 shows the improving trends: during the $1^{\text {st }}$ quarter the plan has been executed with 102.1 percent.

5. Having conducted analysis on the influential factors of collection of budget revenue from VAT, using linear multiple regressive method, it has been proved that weighted VAT rate, average wage, level of employment and the change of consumers' prices impacted the collection of revenue from VAT in the period of 2005-2015. The biggest part of the group of these independent variables of revenue from VAT has been detected evaluating 3 different models. The analysis of the main VAT declaration rates has been conducted and it has been proved that both wholesale and retail sales, the activities of maintenance of engine means of transport and motorbikes as well as manufacturing industry influences the revenue of VAT.

6. In order to increase the efficiency of the revenue from VAT, the main taxation administration in Lithuania is State Tax Inspectorate, together with LR ministry of finance, executing the taxation politics, should take measures to promote the growth of voluntary tax paying. The examples of that policy can be the organised in some countries voucher lottery that encourages customers demand for the proof of the purchase, which ensures the calculation and payment of VAT. The positive influence on the collecting revenue during the longer period of time can be the development and encouragement of consumer's consciousness, providing comprehensible and appealing information to children and constructing their positive attitude towards paying taxes. In addition, the shortening of declaration termination period can have a disciplinary positive influence or effective collecting can be encouraged with the aim to have accurate rates.

\section{References}

Bendikienè, D., Janišauskienė, V. (2005). Pridètinès vertès mokesčio tarifai Lietuvoje ir Europos Sajungos valstybèse/Value Added Tax Tariffs in Lithuania and Europe Union Countries. Socialiniai tyrimai/Social Research, Vol. 1 No 5, p. 26-37.

Bendikienè, D., Šaparnis, G. (2006). Changes in the Imposition of Value Added Tax in Lithuania (1999-2004). Engineering Economics, No 2 Vol 47, p. 23-29.

Bikas, E., Andruskaite, E. (2013). Factors Affecting Value Added Tax Revenue. 1st Annual International Interdisciplinary Conference. Access through internet: http://eujournal.org/index.php/esj/article/viewFile/1230/1239

Bikas, E., Rashkauskas, J. (2011). Value added tax dimension: the case of Lithuania. Ekonomika/ Economics, Vol. 90, No1, p. $22-38$. Access through internet: http://www.zurnalai.vu.1t/ekonomika/article/view/958

Bikas, E., Saikevičius, D. (2010). The Reform of Value-Added Tax in Lithuania: Productivity and Collection Efficiency. 6th International Scientific Conference „Business and Management 2010“. https://doi.org/10.3846/bm.2010.003

Blažytė, V., Norkuvienè, A. (2007). Nacionalinio biudžeto pajamu kitimo tendencijos/Change Tendencies in National Budget Revenues. Jaunųjų mokslininkų darbai/Journal of Young Scientists, Vol. 1 No12, p. 109-118.

Boeters, S., Bohringer, C., Buttner, T., Kraus, M. (2006). Economic Effects of VAT Reform in Germany. Discussion Paper, No 06-030. Access through internet: https://ub-madoc.bib.uni-mannheim.de/1355/1/dp06030.pdf

Damulienè, A., Vengrauskas, V. (2001). Europos Sajungos mokesčiu sistema ir jos ịtaka verslo plètojimui/ Das Steuersystem in der EU und sein Einfluss auf GeschäftsentwicklungJurisprudencija/Jurisprudence, Vol 23 No15, p. 7-18.

Decoster, A., Loughrey, J., O`Donoghue C., Verwerft, D. (2010). How Regressve Are Indirect Taxes? A Microsimulation Analyzis for Five European Countries. Journal of Policy Analysis and Management, Vol. 29, No. 2, p. 326-350. https://doi.org/10.1002/pam.20494

Dilius, A., Kareivaitè, R. (2010). Pridètinès vertès mokesčio tarifo analizé Lietuvoje darnaus vystymosi kontekste/ Value added tax analysis of Lithuania in the context of sustainable development. Vadyba/Journal of Management, No. 17 Vol 1, p. 9-14.

European Union Council directive 2016/112/EC (2006). Official Journal of the European Union. Access through internet: http://eur-lex. europa.eu/legal-content/EN/TXT/PDF/?uri=CELEX:32006L0112\&from=EN. 
Eurostat database. Access through internet: http://ec.europa.eu/eurostat/data/database.

Grinberg, I. (2010). Where Credit Is Due: Advantages of the Credit-Invoice Method for a Partial Replacement VAT. Georgetown Law Faculty Publications and Other Works. 912. Access through internet: http://scholarship.law.georgetown.edu/cgi/viewcontent.cgi?article $=1913 \&$ context $=$ facpub.

Ivaškaitè-Tamošiūnè, V. (2014). Perskirstomasis pridètinès vertès mokesčio vaidmuo Lietuvoje/ Redistributional Role of Value Added Tax in Lithuania. Verslo sistemos ir ekonomika/ Business Systems \& Economics, Vol. 4 No1, p. 30-42. https://doi.org/10.13165/VSE14-4-1-03

Jenkins, G. P., Jenkins H., Kuo, Ch. Y. (2006). Is the Value Added Tax Naturally Progressive? https://doi.org/10.2139/ssrn.897677

Legeida, N., Sologoub, D. (2003). Modeling Value Added Tax (VAT) Revenues in a Transition Economy: Case of Ukraine. Working Paper No. 22. Institute for Economic Research and Policy Consulting.

Liberati, P. (2000). Did VAT Changes Redistribute Purchasing Power in Italy? Working Paper No. 40. http://dx.doi.org/10.2139/ ssrn. 246381

Lietuvos Respublikos finansu ministerija/Ministry of Finance of the Republic of Lithuania. Lietuvos Respublikos 2005-2017 metu valstybès biudžeto vykdymas/Operational data on collection of the state budget. Access through internet: http://finmin.lrv.lt/lt/veiklossritys/biudzetas/valstybes-biudzeto-vykdymo-duomenys-1

Lietuvos Respublikos pridetinès vertès mokesčio ịstatymas/Value Added Tax Act of the Republic of Lithuania. No. IX-751. Valstybès žinios/Official Gazette, 2002, Nr. 35-1271.

Metcalf, G. E. (1995). Value-Added Taxation: A Tax Who's Time Has Come? Journal of Economic Perspectives, Vol. 9, No. 1, p. 121-140. https://doi.org/10.1257/jep.9.1.121

Simionescu, M. (2015). Modelling and Predicting the Indirect Taxes in Romania. Financial Studies, Vol. 2/2015.

Stačiokas, R. (2003). Lietuva ir Europos Sajunga: mokesčiu harmonizavimas/Lithuania and European Union: Tax Harmonization. Ekonomika/ Economics, No. 63, p. 49-65.

Stroe, M. A. (2011). Comparative Analysis of VAT Evolution in the European Economic System. Lex ET Scientia. Economics Series, Lesij no. XVIII, Vol. 1/2011, p. 223-236.

Štreimikienè, D. (2000). Ekonominès taršos mažinimo priemonès Lietuvos energetikoje, juvertinant ES aplinkosaugos reikalavimus/ Economic Tools of Pollution Reduction in Lithuanian Power Sector in the Light of EU Requirements. Inžinerinè ekonomika/Engineering Economics, Vol. 4 No19, p. 26-33.

VMI administruojamų nacionalinio biudžeto pajamų surinkimo apžvalgos 2005-2016 m./ State Budget Revenue Collecting Reviews administered by the State Tax Inspectorate. Access through internet: https:/www.vmi.lt/cms/ataskaitu-archyvas

Egidijus BIKAS, PhD is Associate Professor of Vilnius University, Faculty of Finance. Research interests: fiscal behavioral, public finance, financial behavior, investment portfolio analysis.

Gintautas BAGOTYRIUS is the Lecturer of Vilnius University, Faculty of Finance. Research interests: public finances, fiscal policy.

Agnė JAKUBAUSKAITE் is a PhD student of Vilnius University, Faculty of Finance. Research interests: taxes, taxpayers' behavior. 